\title{
Contextualization of Children's Drawings in the Perspective of Shape and Adaptation of Creation and the Model of Implementation on Learning Art at Elementary School
}

\author{
Zulfi Hendri $^{1}$ \\ Tjetjep Rohendi Rohidi ${ }^{2}$ \\ Suminto A Sayuti ${ }^{3}$ \\ Soesanto $^{2}$

\begin{abstract}
${ }^{1}$ Education of Art Department of Postgraduate Program, Semarang State University and Indonesian Language Departments,

Yogyakarta State University

${ }^{2}$ Educations of Dramatic Art, Dance, and Music Department of

Postgraduate Program, Semarang State University

${ }^{3}$ Indonesian Language Departments, Yogyakarta State University
\end{abstract}

Doi: $10.1515 / m j s s-2017-0027$

\begin{abstract}
The research focused on the contextual problem contained in children's drawing activity. The subjects of the research are the forms (themes, objects, media, and techniques) of drawings made by elementary school-aged children spread over four regencies of Yogyakarta Special Region. In addition, the research also discussed adaptation that influenced the selection of themes, objects, media, and techniques in the work. The study on form and adaptation were subsequently formulated into concepts that can be implemented in art education in elementary schools. The research implemented naturalistic inquiry approach with consideration of the social situation of children when drawing, which is the aspect of places, actors, and activities that interact synergistically. In addition, it also used qualitative method that is an interpretive approach that aims to gain an in-depth knowledge of a phenomenon that occurs at the time the research took place from various point of view of the known subject. The research found that objects drawn by children were drawn from direct and indirect experiences of mountains, beaches, planes, homes, trees, and humans. The themes that appear in children's drawing are themes that are sourced from their daily life (micro cultural) such as playing at a friend's house, fighting, taking a beach vacation, wildfire, and playing at the garden. This happens because of the various backgrounds of residential areas, preferences, television influences and electronic games. Based on these findings, the micro cultural concept becomes a part that should be prioritized in art education for elementary school students to maintain the child's individualism attitude and instill local cultural values.
\end{abstract}

Keywords: shape, adaptation, drawing, implementation

\section{Introduction}

Art for children has many functions, such as improving the creativity of children (Read: 1970), a means of expression (Lowenfeld, 1982), and aesthetic development of children (Read 1978). "Creative" can be interpreted as the ability to produce something new. Expression is a psychological statement of man in communicating the contents of heart. Esthetic development aims 
to make a child grow a refinement or purity of the soul, live the environment, and have ways of thinking that reflect the beauty (Rohidi, 2011). These functions should be a reference for the development of a school curriculum as an aesthetic education.

One form of aesthetic education taught in basic education is drawing. Unfortunately, until now, the implementation of art education in elementary school still has some problems that need to find the right formula to function properly and not merely be a complementary learning course. Some of the causes have been found in research conducted by Hendri et al (2016: 26). The causes of art education in elementary schools are: (1) the competence of teachers of art educators in elementary schools is not sufficient to educate children in drawing activities; and (2) art education is managed by classroom teachers who mostly have insufficient background of knowledge on art education. The cause of inadequate competence of teachers due to the course on art education taken by teachers was merely two credits. In addition, based on information obtained from teachers, teachers are lack of resources which can be used for art education for children.

In addition to the above findings, in fact there are still many problems of contextualization of art that need to be continuously reviewed for the benefit of art education. Art learning in schools today only teaches art in the limits of aesthetic education. In fact, education through and with art is also a construction that needs to be continually strived for implementation, so that art education for children in school really manifests itself as a cognitive leap (Sayuti, 2010). The statement must be in harmony with what Wilson and Wilson (in Brooks, 2002) suggested that art learning for children is not only for the sake of producing fine artistic images, but also to educate the way of thinking and nurture the values of the fineness of the soul and living the environment.

Based on the above problem, the contextual issues of art become more interesting to be studied continuously. What are intended by contextualization art are the cognitive and affective aspects that can make art perfection in the sense of aesthetic education. Contextualization of art will be studied through the form of images and adaptations that support the creation of images as children's artwork. It is expected that the results of the study can be used as a reference consideration of the implementation of art education in elementary school as well as being one of the efforts to familiarize art education.

\section{Literary Review}

This study used child image theory proposed by Ocvirk Et al. and Durkheim. Besides, it also implemented aesthetics based on child image characteristics theory by Read and Viktor Lowenveld and child's typology of Viktor Lowenveld. Rohidi (2011) stated the work of art can be physically seen in the form, style, structure, elements, aesthetic principles, media and techniques, concepts, and ideas of creation. When narrowed in the realm of art, the physical element has three main elements: theme, form, and content or meaning. The theme is basically the object described. In this case, theme is only a creative stimulus. Thus, the end result of the work may be different from the original object form. Therefore, the problem in the creation of art is not what is used as a theme, but rather how one interprets a theme to acquire character (Ocvirk et al., 1962). What is intended by form of the work of art is the whole form of the work. Form is the organization of all the elements of form, such as lines, fields, spaces, textures, and colors. The use of elements of the form relates to physical and psychological relationships. Physical relationships among these elements are based on aesthetic devices that are compositional beauty principles, such as balance, rhythm, domination, and harmony. The use of the principles of this composition is the beauty of artwork. Therefore, the abstract concept of beauty in fine arts can be realized in form organization. The form organization is concerned not only with the visual device but also the materials and tools used in the creation of art (Ocvirk et al., 1962). The content or meaning in the work of art is what is important and hidden in it. Content or meaning is the atmosphere of feeling or experience that one obtains in observing artwork. Content or meaning is also referred to as emotion, mind activity, or association between objects of art with the conscious and unconscious experiences experienced by a person while observing works of art (Ocvirk et al., 1962). In a broader context, content or meaning is the concept of collective thinking. Durkheim (cited in Koentjaraningrat, 2003: 85-86) assumed that psychological activities and processes such as the capture of experiences, tastes, sensations, wills, and desires 
occur within the human physical organism and specifically originate in the brain and his nervous system. Human reason is able to connect the elementary psychological processes through processes into shadows; and all the shadows of a peculiar and favored thing become an idea called réprésentations. This idea can be réprésentations individuelles (individual ideas) and can also be réprésentations collectives. Furthermore, Durkheim argued that the idea that most societies have is no longer a single idea of a peculiar thing, but has generally been associated with other similar ideas, thus becoming the réprésentations collectives. The term réprésentations collectives is then translated into "collective mind" because the word "mind" is broader than the personal "idea" and will become the personality of a person.

Read stated that every child is unique; every child has an aesthetic impulse. Therefore, it is natural that children like to do something that has aesthetic power, such as drawing. In relation to the aesthetics of children's drawings, Read (1958) classified children's images to 12, namely: organic, lyrical, impressionist, rhythmical pattern, structure form, schematic, haptic, expressionist, enumerative, decorative, romantic, and literary. The categories are explicated as follows: (1) Organic: the resulting artwork is based on visual observations of the "artist" with external objects, as an organic unity of relations. In this case the artist likes a clustered object, moving from a separate and silent object; (2) Lyrical: the object is the same as or organic, but prefers static objects, silent as a still-life object with subtle and gentle workmanship; (3) Impressionist: more predominantly the result of catching the situation or mood of the object quickly, which means it is less showing attention to the small parts (detail) contained in the object; (4) Rhythmical pattern: the object of the image is made with rhythmically repeated patterns with various variations so as to meet the field of painting; (5) Structural form: The tendency of children to deform objects into geometric forms which are the essence of external forms; (6) Schematic: uses geometric shapes but breaks away from the bonding of natural object structures. In this case the image of the child tends to accentuate the symbolic than the realistic depiction of the chart; (7) Haptic: shows an unfounded portrayal of the concept of observation, but represents a nonvisual image of the child's own internal world; (8) Expressionist: the child's tendency distorts the shape and color of the object to express feelings spontaneously; (9) Enumerative: the child with his or her eyesight carefully controls the object, records every detail as much as it can be seen and remembered, and describes it in a less organic structure; (10) Decorative: the child utilizes the two dimensional properties in the appearance of the theme organization, the form, or the coloring to create the attractive, fascinating patterns; (11) Romantic: the child takes the themes of life but is intensified by his own fantasy, combined with the reconstruction of his memories and his memories of something related to the theme. (12) Literary: the child uses the themes of stories or fairy tales gleaned from the teacher's reading or tale, which is revealed through the form and color narrative. Nevertheless, children can be said to actually produce works of art if the image has a pleasing in composition and is present for an aesthetic experience (Lansing, 1976).

In addition to Read theory, to study children's drawings, this study also used the theory of development and typology of children according to Victor Lowenfeld (1975), which is visual type" and "haptic type". Visual type is the starting point of appreciation of the child based on observation or visual conception of the natural form around or a viewing object that is understood. In this case, external factors relatively have role, show the plasticity of motion of objects and visual proportions, and use color as a material translation of the object.

In the haptic or non-visual type, the starting point of appreciation of the child is based on his "ideal concept". The characteristics of his paintings are more prominent as expressions of subjective feelings that lead to non-realistic styles, does not seek optical leeway illusion, is not perspective, and shows the motion and proportion of expressive figures, while the use of colors is not as a translation of material objects but rather more evident as a symbol corresponding to his subjective feelings. The division of fine arts of children according to Viktor Lowenfeld and Lambert Brittain is started with the stage of scribbling (2-4 years old). This stage is shown by the child's ability to make unrealized scratches. This stage is divided into three namely; disordered scribbling, controlled scribbling, and naming scribbling. The second stage is the pre schematic stage (4-7 years old). At this stage, there is a change in how to draw i.e. The presence of awareness of the creation of the form and communication with the picture. The characteristic of drawing following the 
hand movements is now transformed into controlled scratches and has a clear connection to the environment because it represents something the child has seen as a person, a house, or a tree. The third stage is the schematic stage (7-9 years old). After satisfied with the experiment of drawing shape, finally the child can start to form a more complete chart. It is called chart if the child makes a shape with repetition without any willingness to change. If a child changes the shape, it is because there is something very important to them. In this period, the child expresses thoughts and feelings in the form of artwork without being limited to what is seen with the eyes only, but rather on what they understand, think, or fantasize about.

Personality, said Koentjaraningrat, consists of elements of knowledge, feelings, and instinct drives. The elements of knowledge are perception, apperception, concept, and fantasy. Associated with perception, Koentjaraningrat described as follows:

In the natural world, there are various things that is received through senses and through other receivers, such as ether vibrations (color and light), acoustic vibrations (sound), smell, taste, touch, mechanical pressure (light-weight), thermal pressure (hot-cold), and others, which enter into various cells in certain parts of the brain. There, various physical, physiological, and psychological processes occur, so that the vibrations and pressures are processed into an arrangement emitted (projected) by the individual concerned into a picture of the surrounding environment (Koentjaraningrat, 2003: 99).

What is meant by feeling is a state in human consciousness is judged positive or negative based on his knowledge. Because of these judgments, feelings are always subjective and usually give rise to the will, both positive and negative. Positive will is the desire of the individual to gain pleasure or satisfaction, whereas the negative will is the desire of the individual to avoid things that do not bring pleasure or satisfaction. The instinct drive is the willingness that is contained in human organisms that arise not because of the influence of knowledge. Individual instinct drives include encouragement to mingle, imitate the behavior of others, worship, and enjoy the beauty (Koentjaraningrat, 2003: 101).

Associated with cultural factors, Irwan Abdullah cites the cultural notion of Clifford Geertz that "Culture is formed from the understandings or meanings that are entirely interwoven in symbols. Through societies, the symbols are transmitted historically and inherited in symbolic form to communicate as well as develop their knowledge and attitudes toward life (Irwan Abdullah, 2010: 1).

\section{Research Methods}

The research used qualitative method to observe children in their environment, interact with them, and try to understand the language and interpretation of children in drawing. Subjects in this study are 7 years old elementary school children as much as 6 people doing drawing activities in the neighborhood of residence, outside school hours and not in the guidance of the studio. The children are from several villages, i.e. Sumberagung village and Kadipiro village in Sleman regency and Poncosari village, Ngijo village, Jl. Parangtritis, Tirtonirmolo, and Mulyodadi village, in Bantul regency of Yogyakarta. The areas were selected based on the consideration that in the villages, there are still many children who are not involved in painting studio and like to draw outside school hours.

This research was conducted within 4 months since August - September 2015 in Yogyakarta. The data in this study refers to the thoughts of Rohidi (2011) which consists of three aspects, (1) the work of art created, in this study it is the image produced by elementary school children at the age of 7 years; (2) what is known to the child involved in the drawing activity during the study; (3) what the child does to the environment and the things that affect the occurrence of a child's idea or idea of drawing. The data is open and the researchers became the instrument participating in the research. Therefore, the techniques used for data collection in this study were observation, interviews, and documentation. The data analysis technique was interactive model of data analysis component proposed by Miles \& Huberman. 


\section{Results and Discussion}

\subsection{Forms of Children's Drawing}

Seen from the structure of fine arts, images produced by 7 -year-old children consist of forms, ideas, and media. The lines are expressed spontaneously by utilizing pencil and markers. The statement is not seen only from mono color images, but also on the full color image as shown in picture 1 and 2 below. In the picture, the child attempts to clarify the form by outlining the other colors either spontaneously or with the aid of a ruler.

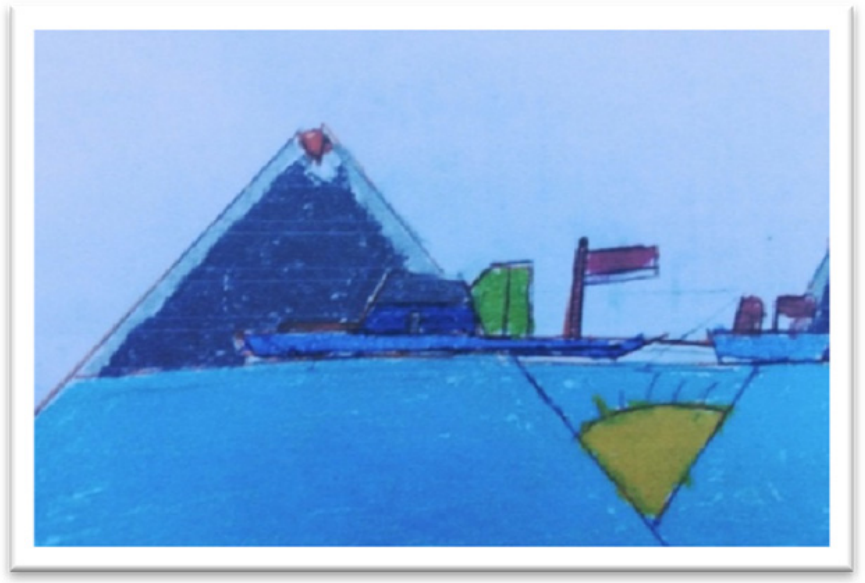

Figure 1. Muhammad Fahri's work entitled Mountain and Sea.

Source: research document

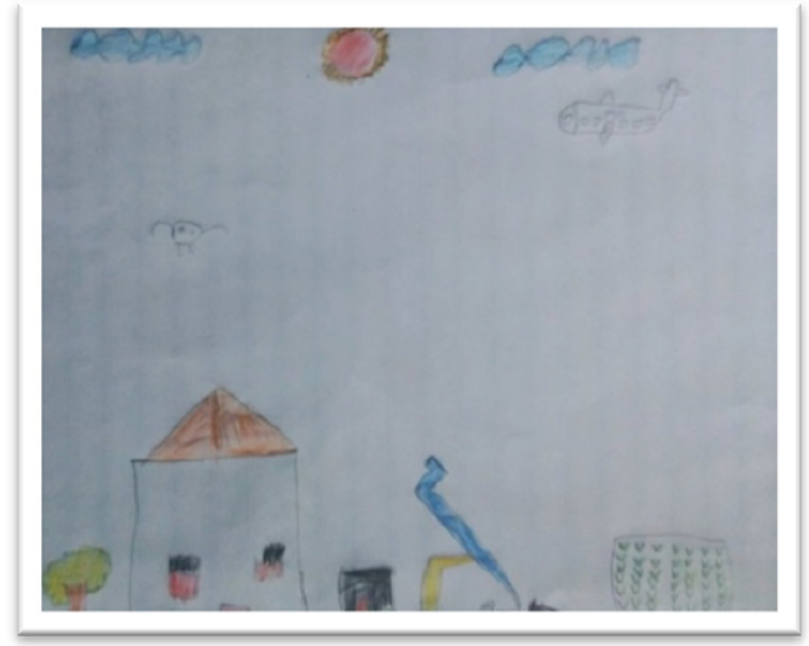

Figure 2. Sidiq Kurnia Sesar's work entitled My friend's house.

Source: research document 
The work of the children can be said as drawing. Drawing is the technique of moving the form of real or imagination power that is poured into paper by giving priority to the line and the field. It means images only use unlined lines with either pencil or dye.

According to Victor Lowenfeld's idea, this picture is categorized as haptic type. This is seen from images that tend toward more visual-emotional or subjective depictions which contain personal expression in responding to events either directly or through the television. Pictures of children of haptic type can be likened to the painting of the style of expressionism. The painting of expressionism is a painting that expresses spontaneous expression of taste and as an objective statement of the inner state. The expressionistic painting seems very subjective impression of the personal freedom of each painter.

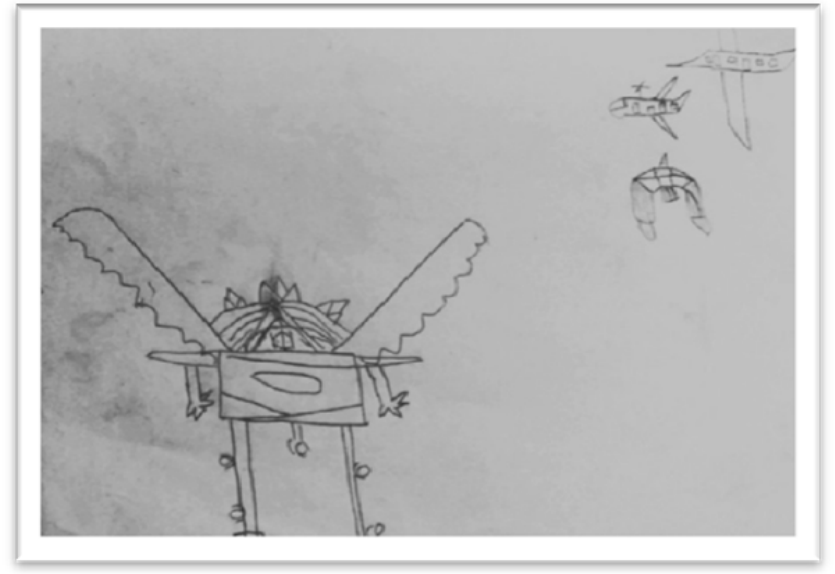

Figure 3. Naufal Rifan Luthfiarta's work entitled Robot

Source: research document

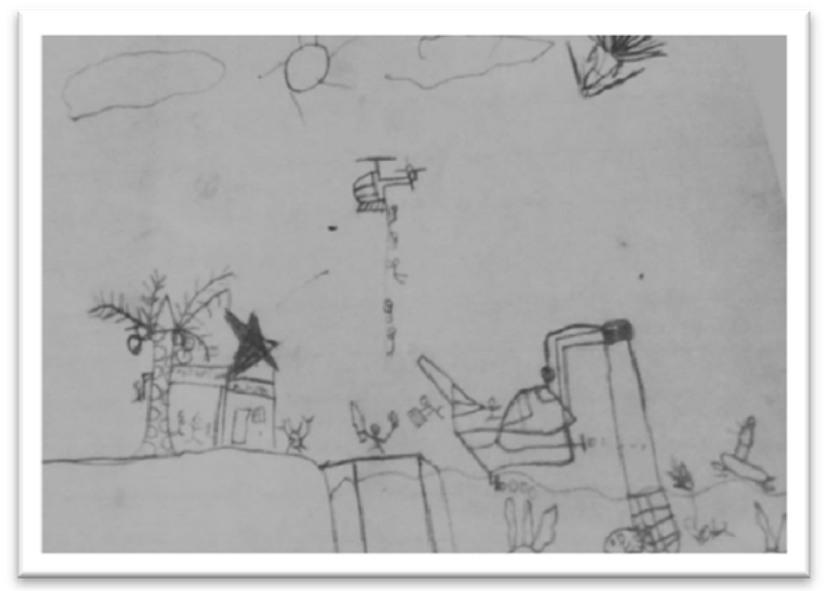

Figure 4. Muhammad Ra'uf Azkabima's work entitled Depok Beach

Source: research document 


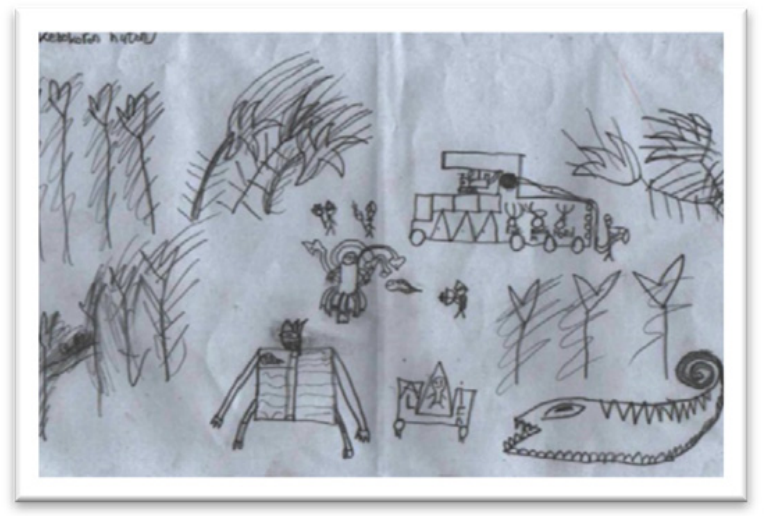

Figure 5. Ahmad Zaky Budianto's work entitled Forest Fire

Source: research document

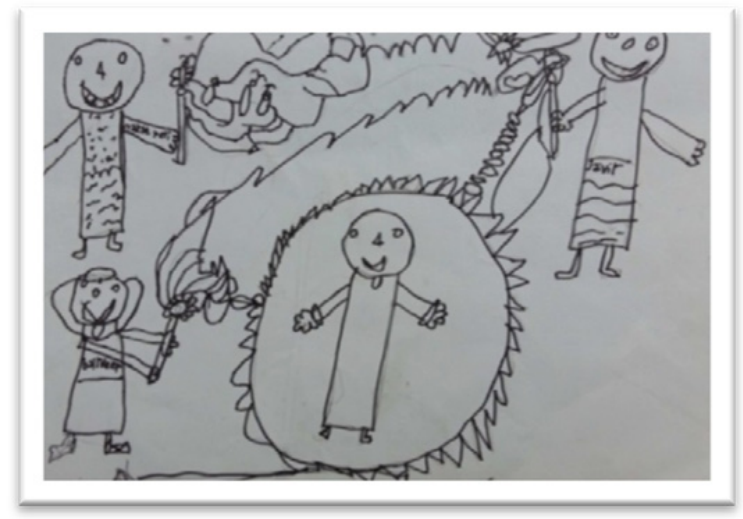

Figure 6. Agustinus Disa Putra's work entitled Baal Veer the Supporter of Goodness Source: research document

\subsection{Adaptation of Children in Drawing}

Watching television and movies has inspired the ideas of 7-year-old children in making artworks. Associated with this research, what is seen as the source of ideas is not television and video but the child's understanding of the characteristics of objects and behaviors in television and video. The acquired knowledge can be regarded as a form of direct adaptation. Because the child sees what he is watching is real.

Based on the exposure of data and discussion of 6 works of children aged 7 years, external factors seem dominant to inspire the theme and ideas of children's work. External factors in a small scale is the environment with various elements of culture in it related to psychological, social, cultural, and natural environment aspects. As Koentjaraningrat has discovered, there are various things that man receives through the senses and through other receivers in the natural world. It enters into cells in certain parts of the brain and is processed physically, physiologically, and psychologically so that it becomes an arrangement that is projected by a child into a work of art and can describe the surrounding environment (Koentjaraningrat, 2003: 99). These characteristics can 
be seen from the various elements that are entirely interwoven in the symbols that the child offers in the work. As seen in the works of Muhammad Fahri and Sidiq Kurnia Sesar, these children bring fascinating stories like the sun in the ocean, heavy equipment in a ship, heavy equipment dredging in the sea, the guns at the end of the ship, and the plunge of the plane. In addition, the elements of the residential environment also inspire the work. Muhammad Ra'uf Azkabima and Ahmad Zaky Budianto present stories about playing on the beach and forest fires. Associated with this, Lowenfeld (1982) argued about art is an act that can make psychiatric statement and serves to meet the needs of human life in seeking satisfaction.

Seen from the diversity of forms of adaptation that influence children imagination, the very individual and subjective nature of the child translating the beauty need to be contained in art education. In addition, environmental diversity in cultural perspectives also encourages the creation of themes in the work of children aged 7 years. Adaptation as in 7-year-old children is actually directly related to cultural factors that exist and apply today. Culture intended as part of the element used as the basis for the creation of works such as various behavior, patterns of thought, association, and harmony in life received/done by members of society (Nazili Shaleh Ahmad, 2010: 36).

It can be concluded that in the work there are three adaptation factors that can influence, (1) knowledge of the objects obtained directly in the area of Yogyakarta, (2) the likes with the location of the playground, and (3) the experience of seeing the objects favored which is also influencing the child to aspire.

\subsection{Art Learning in Elementary School}

\subsubsection{Character-based Microcultural Model}

The concept of art education in Indonesia is already based on cultural diversity. However, the existing format is too big and broad. This concept implies that art education cultivates awareness and appreciation ability to various culture of archipelago and abroad. Basically this concept is good and will enrich children's knowledge. However, based on existing studies, the concept of multicultural is not well understood and appropriate for the benefit of each art learning today. Much of the essence of earthling cultural values is not working.

Based on the analysis of the two issues discussed in this research, which are the shape of the image of children and adaptation that affect the concept of production, micro cultural approach is better implemented in elementary schools for the effective education of fine arts. The word "micro cultural" has a broad understanding, depending on the context of defining and benefits which are expected from the definition. Associated with the basic concept of art education that is related to creative, expressive, and aesthetic, the individual sphere does give the wealth of these values. Every individual has the ability to interact and transact although the background of each culture is different because human nature are; (1) accommodative, (2) associative, (3) adaptable, (4) flexible, and (5) willingness to share.

The concept of micro cultural can be interpreted in the form of individual art education and life. The emphasis is on the "potentials" of the students in the context of their social environment. Thus, the purpose of education as already outlined by Ki Hadjar Dewantara is being independent and responsible for the realization of the meaning of existence as the only God's creature that is virtuous and social. Education, in the view of Ki Hadjar Dewantara, is an education that seeks for the child to develop himself into "mandireng pribadi" (responsible for the realization of the meaning of existence as the only creature of God who is virtuous). Further, Mohamad Said Reksohadiprodjo (1989: 17) explained the nature of education model proposed by Ki Hajar Dewantara that is "handayani" or giving influence. That is the right form of education for the teaching of the arts for children. Children's soul is life, so their learning can be done outside the classroom and in the community. By providing sufficient space, children will be able to activate all the potential that is owned in accordance with their own character. According to Wilhelm Von Humboldt, experience is important in the educational process (Jurgen Oelkers cited in Palmer, 2001: 81). Gradually, what is obtained by children in real or virtual environment will form the ultimate truth. Gutek (1974: 22) wrote, "... education is a process of unfolding that which is latently present in the person...". The 
realism stated that education is the art of communicating truth, while the concept of education is developing understanding. This is in line with John Wild's opinion (cited in Gutek, 1974: 39) that "... education is the art of communicating the truth". Thus, art education in elementary school should be touched on all the joints of the children's life. It would not be possible if art education in schools is only taught based on the existing knowledge of teacher. In addition, micro-cultural-based arts education can also be directed as a cultural process because it aims to provide opportunities to learners so that they understand their lives.

Micro cultural education here is not exactly the same as the multicultural concept, although this is a miniature of multicultural concept that is commonly understood. There are several focuses of dimensions that can be achieved through micro-cultural-based arts education. They are:

a. Making students understand the local culture and becoming the realm of ideas that can be poured in the work;

b. Training students to participate in upholding local cultural values and making children proud of their respective cultures;

c. Giving space to students in achieving diverse academic achievements of characters in one area.

\subsubsection{The Role of Teacher in Microcultural Education}

Teachers are at the forefront of micro cultural learning. The role of teachers is crucial in the successful creation of artwork in schools, especially the process of learning to draw the right for the growth of micro cultural values. Teachers also determine the growing understanding of local culture in a broad sense including in the selection of themes and drawing techniques on learners. What teachers deliver, teaching techniques and teacher's proficiency greatly influence the success of art learning. Teachers who do not have art education background are not culturally sensitive, and have no cultural understanding cannot be expected to succeed in applying micro cultural education in art learning.

Teachers are not only required to have professionalism in the field of study, but also must have extensive knowledge and insight about micro cultural. This is indispensable because each child has his or her own art and culture that shows the extraordinary diversity and richness of local culture. In addition, local culture is also rich in symbols that contain wisdom. The wealth of human, cultural, and natural resources is a great potential to be appreciated and developed for learners. With a wealth of micro cultural insights that teachers see, the richness of the local culture can grow and flourish.

Many elements have created forms in artwork, but the elements in the artwork depend on the medium. Regardless of many elements that exist, micro cultural approach needs to be considered in choosing themes, forms and techniques to create artwork. As we know, learners are located in different areas with different local culture. Therefore, the basic knowledge is very diverse. For instance, the colors of flags by the community to signal the existence of local people who died vary, such as Yogyakarta people use white flag, Klaten people use red flag, while Solo and Semarang people use yellow flag. Thus, although the meaning of the color refers to condolence, it remains an implicit meaning based on the consensus of the local community. This color will bring up a diverse visualization because in the creation of art there are some common knowledge that can be recognized in the learning process, namely: (a) fluency, i.e. the smoothness of ideas stems from a stimulus visual or auditory perception, (b) flexibility, flexible in thinking, able to change and adjust to conditions faced, able to give different perspectives and alternatives in solving problems, (c) elaboration, the ability to develop, equip, enrich, and clarify the simple things into a complete and harmonious unity.

\section{Conclusion}

Based on the result of shape analysis and adaptation of drawing children and the concept of implementation in art learning in elementary school based on contextualization values, it can be concluded as follows:

1. Shapes of children's drawings have the content or meaning of collective thoughts derived naturally from the cultural environment. Various local cultural activities appear in children's 
work such as playing together on the beach, fishing, and forest fires. In addition, it is also seen in the work the psychological processes of each child that is individual (ideals) such as want to become a pilot, a sailor, a great figure, and courageous.

2. Adaptation that influences the emergence of ideas children in Yogyakarta in drawing is the environment with various elements of culture. Culture deals with psychological, social, and cultural aspects such as knowledge of residence, parent occupations, and local environment. This complex knowledge, of course, is not a simple knowledge and cannot be obtained easily. This kind of knowledge is closely related to other knowledge for the sake of knowledge of natural science, social science, mathematics, and good character development.

3. Differences in each child with various cultural and socioeconomic backgrounds have produced drawings of children who are rich in forms, themes, and techniques. The unique values of the local culture of the community have also given birth to the idea of a child's drawing. Thus, concepts based on microcultural education need to be applied in art learning in elementary schools. The concept of microcultural can be interpreted in the form of individual art education and life.

\section{References}

Mahfud, C. (2006). Pendidikan Multikultural. Yogyakarta; Pustaka Pelajar.

Departemen Pendidikan Nasional. (2005). Undang-Undang No.14 Tahun 2005 tentang Guru dan Dosen. Jakarta: Depdiknas.

Dewantara, K. H. (1981). Tamansiswa 30 tahun. Yogyakarta: Printing Tamansiswa.

Eisner, E. W. (1972). Educating Artisrtic Vision. New York: Macmillan Publishing.

Muharam \& Sundaryati, W. (1991). Pendidikan Kesenian II Seni Rupa. Jakarta: Ministry of Education and Culture Directorate General of Higher Education Project for the Development of Education Personnel.

Gollnick, D. M., \& Chinn, P. C. (2006). Multicultural Education in a Pluralistic Society. New York: Pearson Prentice Hall.

Hendri, Z. (2016). Pengembangan Kurikulum Mata Kuliah Reni Rupa untuk Mahasiswa Program Studi PGSD. Yogyakarta: FBS UNY.

Koentjoroningrat. (1990). Pengantar Ilmu Antropologi . New edition. Jakarta: Reneka Cipta.

Lansing, K. M. (1976). Art, Artists and Art Education. New York: McGraw-Hill.

Lowenfel, V. (1975). Described Specific Stages of Growth and Development of Children Based on The Marks They Made. (Online), (http://www.manuals- search-pdf.com/all/victor-lowenfeld.html, di askes Mei 2015).

Lowenfeld, V., \& Brittain, L. W. (1982). Creative and Mental Growth. New York: Mac Milla Publishing Co. Inc.

Miles, M. B. \& Huberman, A. M. (1992). Analisis data kualitatif. (Translator: Tjetjep Rohendi Rohidi). London: Sage Publication. (The original book was published in 1984).

Moleong, L. J. (1998). Metodologi Penelitian Kualitatif. Bandung: Remaja Rosda Karya.

Neuman W. L. (2007). Social Research Method: Qualitative and Quantitative Approach: 6th Edition, Pearson Education, Inc.

Read, H. (1973). Education Trought Art. Translator Katjik Sutjipto. Malang: PPMPT IKIP Malang.

Rohidi, T. R. (1998). Fungi Seni dan Pendidikan Seni dalam Pendidikan Serta Implikasi dalam Pengembangan Kebudayaan. Papers Presented In Higher Education Seminars Fine Arts In Local Realities In The Global Context. 12-13 September 2001. ITB Bandung.

Rohidi, T. R. (2000). Ekspresi Seni Orang Miskin: Adaptasi Simbolik terhadap Kemiskinan. Bandung. Publisher Citra Nuansa.

Rohidi, T. R. (2000). Kesenian Dalam Pendekatan Kebudayaan. Bandung: STISI.

Rohidi, T. R. (2011). Metodologi Penelitian. Semarang: Cipta Prima Nusantara.

Sayuti, S. A. (2010). Pemetaan Seni Pertunjukan dan Tradisi Lisan di Kawasan Geokultural Situs Ratu Boko, Prambanan: Upaya Pengembangan ke Arah Industri Kreatif Sastra dan Seni. Research Report. Yogyakarta: LPPM UNY.

Sayuti, S. A. (2012). Pendidikan Sastra dan Seni Budaya di Era Global: Bagaimana Seharusnya. Prosiding Semnas. Bengkulu.

Wickiser, R. L. (1974). An Introduction to Art of Education. Translation A.J. Soehardjo. Malang: PPMPT IKIP Malang. 